\title{
Available Computational and Physical Models to Understand the Mechanisms of Neonatal Brachial Plexus Injury During Shoulder Dystocia
}

\author{
Anita Singh* \\ Department of Biomedical Engineering, Widener University, Chester, PA
}

Submission: December 04, 2018; Published: January 09, 2019

*Corresponding author: Anita Singh, Biomedical Engineering, Widener University, Chester, USA

\begin{abstract}
Neonatal brachial plexus palsy is a devastating complication occurring during complicated birthing scenarios including shoulder dystocia. To understand the effects of maneuvers that reduce forces required for delivery following shoulder dystocia, tools that simulate the birthing scenarios are needed. Incorporation of brachial plexus responses is further required to help understand the mechanism of neonatal brachial plexus palsy and devise strategies that can help prevent them. Given the inability to measure forces and tissue strains during actual birthing process, computer and physical models serve as optimal tools with its known limitations. This mini-review highlights and summaries available computational and physical models that can help understand brachial plexus injury mechanisms in neonates following complicated delivery including shoulder dystocia.
\end{abstract}

Keywords: Shoulder Dystocia, Neonatal Brachial Plexus Palsy, Computer Model, Physical Model

\section{Introduction}

Shoulder dystocia is failure of the delivery of infant's body and shoulder behind the maternal pubic bone after the delivery of the head. In these complicated birthing scenarios, both endogenous (maternal) and exogenous (clinician-applied) forces can induce damaging forces on the fetal brachial plexus leading to neonatal brachial plexus palsy [1,2]. While animal models are useful in understand the injury outcomes within the brachial plexus and other related tissues, they rarely simulate the birthing scenarios involving the maternal pelvis, clinicians and the involved forces. Computational or physical models can help overcome this limitation and offer insight into the forces involved during neonatal brachial plexus palsy.

\section{Computational Models}

Using a computer simulation model (Madymo, version 5.4, TNO Automotive, Delft, The Netherlands), effects of maternally derived (endogenously-applied loads) and clinician-applied loads (exogenously-applied loads) on fetus brachial plexus have been studied. Using this model, Gonik et al., 2003 reported the forces associated with shoulder dystocia [1]. The study reported exogenous loading forces of 50-100 N resulting in anterior shoulder contact forces of 107 to $127 \mathrm{~N}$. Reported delivery forces were at $100 \mathrm{~N}$ of applied load. Furthermore, maternally derived endogenous forces 100-400 $\mathrm{N}$ led to much higher contact forces (147-272 N) with delivery occurring at $400 \mathrm{~N}$ of maternal force.
The study also reported McRoberts' positioning to result in reduced contact forces when compared to lithotomy positioning. Additionally, downward lateral flexion of the fetal head reported $30 \%$ exogenous load for delivery with little difference in contact force. In another study using the similar model, Gonik et al., 2003 reported that effects of fetal head positioning, sources of applied forces and pelvic orientation on brachial plexus stretch [3].

The study reported a $15.7 \%$ strain (endogenously-applied loads) and $14 \%$ strain (exogenously-applied loads) on the neonatal brachial plexus during lithotomy position. McRoberts positioning reduced the stretch on the brachial plexus for both the endogenously (15.2\%) and exogenously (10.7\%) applied loads. The study also reported a 30\% increase in BP stretch during downward lateral displacement (BP strain of 18\%) of the fetal head when compared to the axial positioning of the head (BP strain of 14\%). Another study by Grimm et al., 2010 used this model and reported the delivery forces and brachial plexus stretch following shoulder dystocia during the application of suprapubic forces, rotation of infant's shoulders and delivery of the posterior arm. They reported a reduction in delivery forces and brachial plexus stretch during all maneuvers when compared to lithotomy alone [4].

\section{Physical Models}

Gonik et al. 1989 reported shoulder extraction forces using a laboratory model of shoulder dystocia [5]. The model included 


\section{Open Access Journal of Neurology \& Neurosurgery}

a maternal pelvic, a fetal model, a tactile sensing glove, and a microcomputer data acquisition system that could measure fetal shoulder extraction forces. Using a variety of fetal biclavicular diameters (10-13 cm) and maternal pelvic angle positions (McRoberts, 10 degrees; lithotomy, 25 degrees) the study reported that McRoberts positioning reduced shoulder extraction forces, brachial plexus stretching, and the incidence of clavicular fracture. In another study, Allen et al., [6] utilized the birthing model to measure clinician-applied extraction forces, moment, and rates for routine, difficult, and shoulder dystocia deliveries. The study reported clinicians averaged $84 \mathrm{~N}$ combined force and $473 \mathrm{~N}-\mathrm{cm}$ neck-bending moment for routine deliveries, $122 \mathrm{~N}$ and $697 \mathrm{~N}-\mathrm{cm}$ for difficult deliveries, and $163 \mathrm{~N}$ and $700 \mathrm{~N}-\mathrm{cm}$ for shoulder dystocia deliveries [6]. In another study Gurewitsch et al. [7] used this laboratory birthing simulator to report the delivery traction force, fetal neck rotation, and brachial plexus elongation after McRoberts', anterior Rubin's, and posterior Rubin's maneuvers. The study reported Rubin's maneuvers to require less traction force than McRoberts'. Furthermore, the brachial plexus stretch was significantly lower after anterior Rubin's maneuver compared with McRoberts' or posterior Rubin's maneuvers [7].

In a more recent study Kim et al. [8] reported a birthing simulator that could help perform research on the delivery process and serve as a clinical training tool [8]. The simulator offers investigators an understanding of complicated birthing scenarios while training them in better assessment and management of these scenarios. The model consists of a maternal model that includes a bony rotatable pelvis, flexible legs, and a uterine expulsive system. The instrumented fetal model consists of potentiometers to measure the neck movements including the extension, rotation, and flexion. The fetal neck model also simulates brachial plexus stretches. Additional force sensing system allows measuring clinician-applied forces during simulated delivery. Preliminary data obtained using this model indicates its biofidelity and offers an ability to provide trainees a correlation between applied forces and BP stretches. No other studies are available using this model.

\section{Discussion and Conclusion}

Neonatal brachial plexus palsy is a devastating complication occurring in 0.5 to 3 cases per 1000 live births [9-11]. One of the reported risk factors for such injuries include shoulder dystocia and studies have reported an increase in the incidence of shoulder dystocia [12]. To understand the effects of maneuvers that reduce forces required for delivery following shoulder dystocia, tools that simulate the birthing scenarios are needed. Incorporation of brachial plexus responses is further required to help understand the mechanism of neonatal brachial plexus palsy and devise strategies that can help prevent them. Given the inability to measure forces and tissue strains during actual birthing process, computer and physical models serve as optimal tools with its known limitations. Overlapping findings of McRoberts' positioning resulting in reduced contact forces when compared to lithotomy positioning enhance the validity of these models in research settings. However, these models do offer some limitations including its match to only one maternal pelvis and an infant. Furthermore, no tissue properties including infant muscle tone and soft tissue resistance of the mother incorporated in these models that affect the delivery process. A more glaring gap is the lack of biomechanical properties of an infant brachial plexus. Better model that overcome these limitations can help better serve as tools that offer an understanding of causation and thereby prevention of neonatal brachial plexus palsy during complicated birthing scenarios.

\section{References}

1. Gonik B, Zhang N, Grimm M (2003) Defining forces associated with shoulder dystocia: Use of dynamic computer model (MADYMO). Am J Obstet Gynecol 188(4): 1068- 72.

2. Gonik B, Walker A, Grimm M (2000) Mathematic modeling of forces associated with shoulder dystocia: a comparison of endogenous and exogenous sources. Am J Obstet Gynecol 182(3): 689-691.

3. Gonik B, Zhang N, Grimm MJ (2003) Prediction of brachial plexus stretching during shoulder dystocia using a computer simulation model. Am J Obstet Gynecol 189(4): 1168-72.

4. Grimm MJ, Costello RE, Gonik B (2010) Effect of clinician applied maneuvers on brachial plexus stretch duringa shoulder dystocia event: investigation using a computer simulation model. Am J Obstet Gynecol 203(4): 339.

5. Gonik B, Allen R, Sorab J (1989) Objective evaluation of the shoulder dystocia phenomenon: effect of maternal pelvic orientation on force reduction. Obstet Gynecol 74(1): 44-48.

6. Allen RH, Bankoski BR, Butzin CA, Nagey DA (1994) Comparing clinician-applied loads for routine, difficult, and shoulder dystocia deliveries. Am J Obstet Gynecol 171(6): 1621-1627.

7. Gurewitsch ED, Kim EJ, Yang JH, Outland KE, McDonald MK, et al. (2005) Comparing McRoberts' and Rubin's maneuvers for initial management of shoulder dystocia: an objective evaluation. Am J Obstet Gynecol 192(1): 153-60.

8. Kim JE, Theprungsirikul P, McDonald MK, Gurewitsch E, Allen RH (2005) A biofidelic birthing simulator. Models for research and training in complicated human births. IEEE Eng Med Biol Mag 24(6): 34-39.

9. Evans-Jones G, Kay SP, Weindling AM, Cranny G, Ward A, et al. (2003) Congenital brachial palsy: incidence, causes, and outcome in the United Kingdom and Republic of Ireland. Arch Dis Child Fetal Neonatal Ed 88(3): f185-189.

10. Gilbert WM, Nesbitt TS, Danielsen B (1999) Associated factors in 1611 cases of brachial plexus injury. Obstet Gynecol 93(4): 536-540.

11. Mollberg M, Hagberg H, Bager B, Lilja H, Ladfors L (2005) High birthweight and shoulder dystocia: the strongest risk factors for obstetrical brachial plexus palsy in a Swedish population-based study. Acta Obstet Gynecol Scand 84(7): 654-659.

12. Dandolu V, Lawrence L, Gaughan JP, Grotegut C, Harmanli OH, et al. (2005) Trends in the rate of shoulder dystocia over two decades. J Matern Fetal Neonatal Med 18(5): 305-310. 
CC (1) This work is licensed under Creative (1) Commons Attribution 4.0 Licens

DOI: 10.19080/OAJNN.2019.09.555768
Your next submission with Juniper Publishers will reach you the below assets

- Quality Editorial service

- Swift Peer Review

- Reprints availability

- E-prints Service

- Manuscript Podcast for convenient understanding

- Global attainment for your research

- Manuscript accessibility in different formats ( Pdf, E-pub, Full Text, Audio)

- Unceasing customer service

Track the below URL for one-step submission https://juniperpublishers.com/online-submission.php 